\title{
Okullarda Örgütsel Adalete İlişkin Öğretmen Deneyimlerinin İncelenmesi ${ }^{1}$
}

\author{
DOI: 10.26466/opus.711001
}

\author{
*Nuray Özge Sağbas ${ }^{*}-$ Murat Özdemir ${ }^{* *}$ \\ *Dr., Şube Müdürü, Milli Eğitim Bakanlığı, Ankara/Türkiye \\ E-Posta: nurayozgesagbas@hotmail.com \\ ORCID: $0000-0003-2630-8620$ \\ ** Prof.Dr., Hacettepe Üniversitesi, Eğitim Fakültesi, Ankara/Türkiye \\ E-Posta: mrtozdem@gmail.com \\ ORCID: 0000-0002-1166-6831
}

\begin{abstract}
Öz
Okullarda görev yapan öğretmenlerin olumlu ve olumsuz işgören davranışı sergilemelerinin çeşitli nedenleri bulunmaktadır. Bu nedenlerden biri de örgütsel adalet algisıdır. Alanyazın taramalarında öğretmenlerin örgütsel adalete ilişkin okul içi uygulamaları nasıl deneyimlediklerine ve anlamlandırdıklarına yönelik nitel çalışmaların görece az olduğu görülmüştür. Bu bağlamda araştırmanın amacı okul yönetim süreçlerinde adil olmayan uygulamalara yönelik öğretmen deneyimlerini keşfetmektir. Araştırma olgubilim desenine dayal yürütülmüştür. Araştırma verisi Ankara ilinde görev yapan 8 öğretmenle odak grup görüşmesi, 11 öğretmenle de görü̧̧me yoluyla toplanmıştır. Veriler içerik analizi ile çözümlenmiştir. Çözümleme sonucunda öğretmenlerin adil olmayan yönetsel uygulamalar karşısındaki deneyimlerinin olumsuz duygular ile duygusal ret olmak üzere iki tema altında toplandığı gözlenmiştir. Çalışmada ayrıca yönetsel uygulamalara yönelik adalet algısının değerlendirilmesinde ise örgütsel adaletin dağıtım, süreç ve etkileşimsel adalet alt boyutlar birer tema olarak değerlendirilmiştir. Bu kapsamda katılımcılar en fazla süreç adaleti temasında adil olmayan uygulamalara maruz kaldıkların ifade etmişlerdir. Araştırmada öğretmenler arasında muhalefet etme, kayıtsız kalma, işten ayrılma, sadakat gösterme ve bilgi uçurma davranışlarının yönetim süreçlerindeki adalete yönelik tepkiler olduğu ortaya çıkarılmıştır.
\end{abstract}

Anahtar Kelimeler: Örgütsel adalet, İşten ayrılma, Muhalefet etme, Sadakat, Kayıtsız kalma.

\footnotetext{
${ }^{1}$ Bu çalışma Dr. Nuray ÖZGE SAĞBAŞ’ın Hacettepe Üniversitesi Eğitim Yönetimi Doktora Programında Prof. Dr. Murat ÖZDEMiR danışmanlığında tamamlamış olduğu "Okullarda Ayrılma, Kayıtsız Kalma, Muhalefet ve Sadakat ile Örgütsel Adalet ilişskisinde İ̧̧ Doyumunun Aracı Etkisi" başlıklı tezinden türetilmiştir.

This study is derived from Dr. Nuray ÖZGE SAĞBAŞ's thesis titled "The mediating effect of job satisfaction on the relation between organizational justice and voice, neglect, exit, and loyalty in schools", which she completed under the supervision of Prof. Dr. Murat ÖZDEMiR in the Education Management Doctorate Program of Hacettepe University.
} 


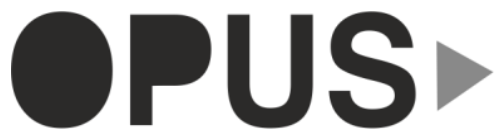

Uluslararası Toplum Araştırmaları Dergisi International Journal of Society Researches
E-ISSN : 2528-9535

YIl Year: 10

Cilt Volume: 16

Sayı Issue :Eğitim ve Toplum Özel Sayı

Nisan April 2020

Makalenin Geliş Tarihi Received Date: 29/03/2020

Makalenin Kabul Tarihi Accepted Date: 29/12/2020

\title{
Examination Of Teacher Experiences Regarding Organizational Justice In Schools
}

\begin{abstract}
There are several reasons why teachers working in schools display positive and negative employee behaviors. One of these reasons is the perception of organizational justice. In the literature review, it was seen that the qualitative studies on how teachers experience and make sense of in-school practices related to organizational justice were relatively low. In this context, the purpose of this study is to discover teacher experiences regarding unfair practices in school management processes. The study was carried out based on the phenomenology design. The research data were collected through eight group teachers working in Ankara and focus group meetings and 11 teachers. The data were analyzed by content analysis. As a result of the analysis, it was observed that the teachers' experiences related to unfair administrative practices were gathered under two themes: negative emotions and emotional rejection. In the study, the distribution, process and interactional justice sub-dimensions of organizational justice were evaluated as a theme in evaluating the perception of justice for managerial practices. Within this scope, the participants stated that they were exposed to unfair practices mostly in the theme of procedural justice. In the research, it was revealed that the behaviors of exit, voice, neglect, loyalty and whistleblowing among teachers are justice in the management processes.
\end{abstract}

Keywords: Organizational justice, Exit, Voice, Loyalty, Neglect 


\section{Giriş}

Son yıllarda yapılan araştırmalar ve istatistiki veriler incelendiğinde öğretmenlerin gerek isteğe bağlı gerekse özre bağlı tayin istediği ve yer değiştirdikleri görülmektedir. Örneğin 2018- 2019 Eğitim- Öğretim yılında ülke genelinde resmi okullarda görev yapan öğretmenlerin yaklaşı $\% 15$ 'nin yer değiştirdiği istatistiki verilerle ortaya konulmaktadır [Milli Eğitim Bakanlığ (MEB), 2019]. Öğretmenlerin görev yaptıkları okullardan ayrılmak istemelerinin çeşitli sebepleri olabilir. Bu sebeplerden biri de öğretmenlerin adalet algılarıdır.

Araştırmalar adalet algısı düşen öğretmenlerin örgütsel adalete bağlı olarak işten ayrılma (exit) davranışı sergilediğine vurgu yapmaktadır (Hirschman, 1970; Tulunay Ateş ve Önder, 2017; Uysal, 2014). Gunn, Rusbult ve Zembrodt (1982)'a göre işten ayrılma davranışıı, yeni bir iş arama ya da başka bir iş yerine geçme durumunu ifade etmektedir. Örgütsel adalet algısı düşük öğretmenlerin vermiş olduğu tepkilerden bir diğeri ise muhalefet etme davranışıdır (voice). Bazen de öğretmenler düşen adalet algısından dolayı kendi ihtiyaçlarından önce çalıştıkları örgütün ihtiyaçlarına öncelik vermekte mesai saatleri dışında da çalışmaya devam etmektedir. Sadakat (loyalty) olarak adlandırılan bu boyutta öğretmenler şartların iyileşmesini umarak sabırla beklemektedirler (Grima ve Glaymann, 2012; Hirshman, 1970; Özsoy Özmen, 2017).

Adalet algısı düşen öğretmenler, işten ayrılma, sadakat ve muhalefet etme davranışlarına ek olarak bazen de örgütteki yaşanan sorunlara ve olaylara karşı kayıtsız kalarak (neglect) pasif davranış sergilemektedir (Farrell, 1983; Özsoy Özmen, 2017; Withey ve Cooper, 1989). Belirtildiği gibi öğretmenlerin çalışma ortamına yönelik örgütsel adalet algıları onların işten ayrılma, muhalefet etme, sadakat ve kayıtsız kalma davranışlarını sergilemelerinde etkili olmaktadır (Çelik, 1987; Eklund, 2009; Hirschman, 1994; Leck ve Saunders, 1992).

Alan yazın incelendiğinde adalet kavramının Aristo, Platon (Eflatun), Sokrates tarafından da çalışılmış olduğu anlaşılmaktadır. Aristo; adalet kavramını insan davranışlarının doğruluğu hakkında bilgi veren ilkeler bütünü olarak tanımlarken; Platon ise mutlu ve huzurlu yaşam için her insanın kendi işi ile ilgili olması şeklinde ifade etmiştir (akt.Colquitt, Greenberg ve Zapata-Phelon, 2005; Çıvgın, 2018; Topakkaya, 2009). Örgütsel adalet kav- 
ramının temeli Adams'ın Eşitlik Kuramı'na dayanmaktadır. Bu kurama göre çalışanlar, kendilerinin ve başkalarının girdilerini ve sonuçlarını (maaş, ödüllendirme vb.) gözden geçirmekte ve eğer girdi- çıtı arasında eşitsizlik algılanırsa çalışanlar eşitliği yeniden kazanmaya çalışmaktadır (Luthans, 2011).

Örgütsel adalet sözcüğü Greenberg tarafından ilk defa 1987'de çalışanların örgütteki uygulamalar ve örgütte alınan kararların adil olduğuna ilişkin çalışan algılamaları ve bu algılamaların da çalışan davranışları üzerindeki etkisini açıklamak üzere kullanılmıştır (Greenberg, 1987). Örgütsel adalet kavramını İçerli (2010) yöneticilerin örgüte ve çalışanlara ilişkin aldıkları karar ve uygulamalarının, çalışanlarca olumlu algılanması; Altınkurt ve Yılmaz (2010) çalışanların örgütteki paylaşım, işlem, süreç ve iletişime ilişkin algısı olarak tanımlamıştır. İşcan ve Sayın (2010) ise örgütsel adaletin, örgüt içinde çalışanlara karşı adil uygulamaları ve bu algılamaların örgüte ilişkin sonuçları üzerindeki etkilerini içeren bir sözcük olduğunu ifade etmiştir.

Tarihsel süreci incelendiğinde örgütsel adalet kavramın dağıtım adaleti, süreç adaleti ve etkileşimsel adalet şeklinde üç boyutta incelendiği görülmektedir. Dağıtım adaleti, çalışanlar tarafından edinilen kazanımların adaletli dağıtılıp dağıtılmadığına ilişkin algılamaları ifade eder (Folger ve Konovsky, 1989). Çalışanlar, örgüt içinde elde ettiği kazanımları diğer çalışanlarla karşılaştırır. Kazanımlar arasında denge olduğunu gören çalışan bu durumda eşitliğin sağlandığına inanır. Ortada eşit olmayan bir durumun varlığı algılandığında ise çalışan sergilediği performansı azaltarak ya da örgütten ayrılarak bu eşitliği sağlamaya çalışır (Eren, 2011).

Örgütsel kararların adil alınmasına neden olan süreci inceleyen süreç adaleti, çalışanların örgütlerde alınan kararların alınma biçimine gösterdiği tepkiler üzerine odaklanmaktadır (Poyraz, Kara ve Çetin, 2009 2009). Doğan (2002)'a göre süreç adaleti (i) ücret, (ii) görevde yükselme, (iii) maddi imkanlar, (iv)çalışma ortamına ilişkin koşullar ve (v) çalışanların performanslarının değerlendirilmesinde kullanılan yöntem, teknik ve politikaların adil olması ile ilgilenmektedir. Leventhal (1980, s.39)'a göre süreç adaleti ayrıca yöntemlerin çalışanlar tarafından adil olarak algılanması ve (i) dağıtıma ilişkin kararların birbiri ile tutarlı olmasını ifade eden tutarlılık kuralı, (ii) dağıtıma ilişkin çalışanlara karşı tarafsız olmayı ifade eden ön yargılı olmamak kuralı, (iii) paylaşıma ilişkin bilgilerin doğru olmasını ifade eden doğ- 
ruluk kuralı, (iv) alınan kararlara çalışanların itiraz edebilmesini ve gerektiğinde de düzeltilmesini ifade eden düzeltebilme kuralı, (v) çalışanların kendi düşüncelerini ifade edebilmelerine olanak tanıyan temsilci seçilebilmesi ve bu temsilcinin görüş sunmasını ifade eden temsilcilik kuralı, (vi) dağıtım ve sürece ilişkin alınan kararlara iliş̧in etik değerlerin çalışanların etik değerleri ile örtüşmesini ifade eden etik kural olmak üzere altı kuralı içermesi gerektiğini ifade etmektedir.

Bies ve Moag (1986) tarafından ilk kez kullanılan etkileşimsel adalet, çalışanlara yöneticiler tarafından yeterince adil davranıldığını değerlendirmeleri için (i) çalışanlara saygı duyulması, (ii) çalışanların kararlara ilişkin bilgilendirilmeleri, (iii) çalışanlara karşı dürüst olunmasına ilişkin değerleri içermektedir (Skarlicki ve Folger, 1997). Mikula, Petri ve Tanzer (1990) tarafından yapılan araştırma, günlük hayatta insanların haksız olduğunu düşündüğü olay türlerini belirlemek ve bu tür olayların anlamlı bir yapısal temsilini bulmak için tasarlanmıştır. Yapılan çalışmada bireylerden adil olmayan olayları listelemeleri istenmiş, bu listeleme sonucunda elde edilen 280 olay incelendiğinde adil olmayan uygulamaların bireylerarası etkileşime ait davranışları içerdiği sonucuna ulaşılmıştır. Araştırma sonuçları ise bireylerin kendilerine yapılan saygısız ve kaba davranışları adil olarak değerlendirmediklerini göstermektedir.

Örgütsel adalet algısı düşen ve çalıştığı örgütün performansından memnun olmayan çalışan, işten ayrılarak örgütle bağlarını koparabilir. İşten ayrılma davranışı; işten ayrılmayı, başka bir örgütte işe başlamayı ya da yeni bir iş arayışında bulunma eylemlerini içermektedir (Rusbult, Farrell, Rogers ve Mainous, 1988). Hirschman (1970) ise işten ayrılma davranışını örgütler için en istenmeyen durum olarak tanımlamaktadır. İşten ayrılma davranışı örgütlerde iş gücü devrine neden olduğu için yıkıcı bir davranış olarak değerlendirilmektedir (Rusbult, Zembrodt ve Gunn, 1982). Yapılan araştırmalar, çalışanın işten ayrılma davranışı sergilemesinde (i) kişisel faktörler, (ii) örgütsel ve işe ilişkin faktörler, (iii) sosyal ve ekonomik faktörlerin etkili olduğunu ifade etmektedir (Zhang, 2016).

Örgütsel adalet algısı algısı düşen çalışanın verdiği bir başka tepki biçimi de muhalefet etmedir. Özsoy Özmen (2017)'e göre muhalefet etme davrantşı, örgütün faydasına olan bir tepki şeklidir. Hirschman (1970) muhalefet etme davranışı örgüt içinde istenmeyen bir durumu değiştirmeye yönelik çabayı içerdiğini belirtmektedir. Rusbult ve arkadaşları (1988) ise muhalefet 
etme davranışının çalışanın örgütteki sorun alanları hakkında ilgili yöneticiler ya da çalışma arkadaşları ile konuşma eylemini kapsadığını ifade etmektedir. Kassing ve Armstrong (2002) tarafından yapılan çalışmada örgütlerde çalışanlar arasında muhalefet etme davranışını başlatan eylemler dizisini (i) çalışanlara karşı sergilenen eylemler, (ii) örgüte ilişkin değişim, (iii) kararın verilmesi, (iv) verimsizlik, (v) rol ve sorumluluk, (vi) kaynaklar, (vii) etik, (viii) performansın değerlendirilmesi, (ix) zararların önlenmesi şeklinde sıralamışlardır.

Sadakat, örgütsel adalet algısı düşen çalışanlar tarafından verilen bir başka tepki biçimidir. Sadakat kavram olarak içten bağlllık, duygu ve düşüncede sağlam duruş, ihanet davranışında bulunmama anlamlarına gelmektedir (Koç, 2002; s.49). Örgütsel anlamda sadakat kavramı Graham (1991) tarafından örgüt çalışanlarının örgüte yönelik tehdidi engellemek ve itibarına katkı sağlamak, örgütün bütünsel düzeyde çıkarına hizmet etmek için başkalarıyla işbirliği yaparak kendini örgüte adaması olarak tanımlanmıştır. Hirschman (1970) ise sadakat tepkisinin işten ayrılma ve muhalefet etme tepkileri arasında yer alan ılıman bir davranış olduğunu belirtmiştir. Alan yazın incelendiğinde örgütsel sadakat davranışı ve örgütsel bağlllık kavramlarının iç içe geçen kavramlar şeklinde kullanıldığı görülmektedir. Örgütsel bağlılık kavramı, örgüt çalışanının örgütte kalmaya istekli olması ya da örgütten ayrılma kararı vermesi durumuna attfta bulunmaktadır (Meyer ve Allen, 1991) ve çalışana ilişkin bireysel faydaya yönelik davranışları içermektedir. Örgütsel sadakat ise örgütsel bağlllığa göre daha güçlü duygu içeren tek yönlü ve çalışan için karşılığının olmama ihtimali bulunan örgütsel bağlılığın sonucu ve örgütsel faydanın ön planda olduğu bir eylemdir (Koç, 2009).

Örgütsel adalet algısı düşen çalışan kayıtsız kalma davranışı şeklinde de tepki göstermektedir. Kayıtsız kalma davranışı, çalışanın örgütteki çalışma arkadaşları ile daha az zaman geçirme, çalışma arkadaşlarını görmezden gelme, örgüte ilişkin sorunları tartışmayı reddetme, örgüte yönelik eleştirme davranışında bulunmaya yönelik tepkileri içermektedir. Kayıtsız kalma davranışı sergileyen çalışan pasif durumdadır ve iş doyumsuzluğunu önlemek için yapılacak eylemlerin yarar sağlamayacağını düşünmektedir (Farrell, 1983; Rusbult vd., 1982; Withey ve Cooper, 1989).

Eğitim örgütleri odaklı alan yazın taramalarında örgütsel adaletin kimi örgütsel çıktılar üzerindeki etkilerinin neler olduğunun sorgulandığı gö- 
rülmektedir. Ertürk (2003) yaptığı çalışmada örgütsel iletişim ve örgütsel adalet algısının çalışanlarda örgütsel kimlik oluşumunu etkilediği sonucuna ulaşmıştır. Lee ve Wilbur (1985) tarafından yapılan araştırmada örgütsel adalet ile iş doyumu arasında pozitif yönde anlamlı ilişki bulunduğu ve örgütsel adaletin alt boyutlarının iş doyumunun anlamlı yordayıcları olduğu sonucuna ulaşılmıştır. Kavak ve Kaygın (2018) tarafından yapılan bir diğer çalışmada ise örgütlerde örgütsel adalet uygulamaları ile muhalafet etme davranışı arasında anlamlı bir ilişki olduğu belirlenmiştir.

Okullarda adaletin düşük olmasının yol açtığı açtı̆̆ 1 sonuçların araştırmacılar tarafından genelde örgütsel adalet ve iş doyumu (Altınkurt ve Yılmaz, 2014; Clay-Warner, Reynolds ve Roman, 2005), örgütsel adalet ve işten ayrılma (Örücü ve Özafşarlığlu, 2013), örgütsel adalet ile sadakat (Fischer, 2004; Önder ve Tulunay Ateş, 2017), örgütsel adalet ile kayıtsız kalma (Withey ve Cooper, 1989) olmak üzere iki değişken şeklinde incelendiği görülmektedir. Aynı zamanda bütün bu çalışmaların öğretmenlerin örgütsel adalete ilişkin algılarını, kimi değişkenlerle ilişkisini nicel teknikler kullanarak incelediği de saptanmıştır. Yerli alanyazın taramalarında öğretmenlerin örgütsel adalete ilişkin okul içi uygulamaları nasıl deneyimledikleri ve anlamlandırdıklarına yönelik nitel teknikler kullanılan yapılan çalışmalara ise rastlanamamıştır. Okullarda örgütsel adalet algisı düşen öğretmenlerin ne tür tepkiler verdikleri de benzer şekilde nitel bir yaklaşımla daha önce sorgulanmamıştır. Öğretmenlerin örgütsel adalete ilişkin yaşantılarını nasıl anlamlandırdıkları ve bu anlamlamlandırmaya dayalı olarak okullarda ne tür davranışlar sergilediklerinin nitel bir çalışmayla keşfedilmesinin ilgili alanyazına katkı sunması umulmaktadır. Çalışmada elde edilen sonuçların örgütsel adalet uygulamalarının okul bazında iyileştirme süreçlerine de katkı sunması beklenmektedir. Bu kapsamda araştırmada aşağıdaki sorulara yanit aranmiştır;

1. Öğretmen görüşlerine göre okullarda adil olmayan yönetsel uygulamalar nelerdir?

2. Adil olmayan uygulamalar karşısında öğretmenlerin vermiş olduğu duygusal tepkiler nelerdir?

3. Adil olmayan uygulamalar karşısında öğretmen davranışları nelerdir? 


\section{Yöntem}

\section{Araştırma Modeli}

Öğretmenlerin okullardaki adalet uygulamalarına karşı görüşlerinin incelendiği bu çalışma, nitel araştırma yaklaşımına dayalı yürütülmüştür. Araştırmada nitel araştırma desenlerinden olgubilim temel alınmış; öğretmen görüşleri doğrultusunda öğretmenlerin okullardaki adalet uygulamalarına ilişkin deneyimlerinin neler olduğu ortaya çkarılmıştır.

\section{Çalışma Grubu}

Araştırma çalışma grubu, 2019-2020 eğitim-öğretim yılında Ankara ilindeki devlet okullarında görev yapan toplam 19 katılımcı öğretmenden oluşmaktadır. Araştırma sürecinde ilk olarak sekiz öğretmenin katılımıyla odak grup görüşmesi yapılmıştır. Bu büyüklükteki bir katılımcının odak grup görüşmesi için yeterli olduğu belirtilmektedir (Çokluk, Yılmaz ve Oğuz, 2011). Ancak sekiz öğretmenden odak grup görüşmesi yoluyla toplanan verinin analizi sürecinde veri doygunluğuna ulaşılmamış olduğu görülmüştür. Bu gerekçeyle odak grup görüşmesi sonrasında ilave bir onbir öğretmen ile yarı yapılandırılmış görüşme formu kullanılmak suretiyle yüzyüze görüşmeler gerçekleştirilmiştir. Çalışma grubunun belirlenmesinde amaçlı örnekleme yöntemi kullanılmış; kartopu örnekleme yöntemine başvurulmuştur. Bu kapsamda ölçüt olarak öğretmenlerin en az beş yıl tecrübeye sahip olması ve şu anki okullarında bir yıl ve daha fazla süredir çalışması, örgütsel adalet uygulamaları konusunda yaşantılarının bulunması şartı aranmıştır. Bu şekilde öğretmenlerin okullardaki adalet uygulamalarına karşı görüşlerinin belirlenmesi amaçlanmıştır. Katılımcılara ait kodlar, cinsiyet, yaş, kıdem ve branş bilgilerine ilişkin demografik bulgular tablo 1'de sunulmuştur. 
Tablo 1. Katılımcılara ilişkin bilgiler

\begin{tabular}{lllll}
\hline Katılımc1 & Cinsiyet & Yaş & Kıdem & Branş \\
\hline Ö1 & Kadın & 29 & 7 & Biyoloji \\
\hline Ö2 & Kadın & 30 & 8 & Müzik \\
\hline Ö3 & Erkek & 43 & 20 & Türk Dili ve Edebiyatı \\
\hline Ö4 & Kadın & 47 & 25 & Biyoloji \\
\hline Ö5 & Erkek & 48 & 25 & Fizik \\
\hline Ö6 & Erkek & 41 & 19 & Kimya \\
\hline Ö7 & Kadın & 42 & 20 & Türk Dili ve Edebiyat1 \\
\hline Ö8 & Erkek & 48 & 26 & Türk Dili ve Edebiyat1 \\
\hline Ö9 & Erkek & 35 & 11 & Din Kültürü ve Ahlak Bilgisi \\
\hline Ö10 & Erkek & 41 & 18 & Türk Dili ve Edebiyatı \\
\hline Ö11 & Kadın & 27 & 5 & Kimya \\
\hline Ö12 & Kadın & 41 & 20 & Tarih \\
\hline Ö13 & Erkek & 47 & 18 & Din Kültürü ve Ahlak Bilgisi \\
\hline Ö14 & Kadın & 38 & 15 & İnilizce \\
\hline Ö15 & Erkek & 49 & 19 & Görsel Sanatlar \\
\hline Ö16 & Erkek & 40 & 8 & Beden Ĕ̈itimi \\
\hline Ö17 & Erkek & 43 & 18 & Kimya \\
\hline Ö18 & Erkek & 41 & 20 & Matematik \\
\hline Ö19 & Erkek & 54 & 30 & Coğrafya \\
\hline
\end{tabular}

Tablo 1'den de izleneceği gibi katılımcılara ilişkin yaş, kıdem ve branş düzeyindeki bilgiler homojendir.

\section{Veri Toplama Araçlan}

Araştırmanın verileri, yarı yapılandırılmış görüşme formu kullanılarak toplanılmıştır. Görüşme formu oluşturulurken araştırmada yanıt aranan sorulara ilişkin açık uçlu hazırlanan sorular ve sonda sorular hazırlanmıştır. Türnüklü (2000)'ye göre yarı yapılandırılmış görüşme formları, araştırma yapan kişiye alternatif olacak ve sonda sorular sorma yoluyla esneklik kazandırmaya katkı sağlamaktadır. Araştırma sorularının araştırma amacına uygun olup olmadığının belirlenebilmesi, kapsam geçerliği ile dil yönünden uygunluğun sağlanması için iki alan uzmanı ile dil uzmanı olan kişilerden destek alınmıştır. Araştırmadaki temel sorular ile sonda soruların anlaşılırlığ1 ve sorularda kullanılan ifadelerin katılımcılara uygunluğunu test etmek amacıyla araştırma kapsamında olmayan farklı beş öğretmenle pilot uygulama yapılmıştır. Verilen dönütler ışığında gerekli düzenlemeler yapılarak yarı yapılandırılmış görüşme formuna nihai hali verilmiştir. Görüşme formundaki sorular şöyledir "Okullarda adil olmayan uygulamalar nelerdir?", "Adil olmayan uygulamalar karşısında öğretmenlerin vermiş olduğu duy- 
gusal tepkiler nelerdir?" ve "Adil olmayan uygulamalar karşısında öğretmen davranışları nelerdir?".

\section{Veri Toplama Süreci}

Araştırmaya katılım, gönüllülük esasına dayalı olarak gerçekleștirilmiştir. Çalışmanın yürütülebilmesi için Etik Komisyon izni ile Ankara İl Milli Eğitim Müdürlüğünden yasal izin alınmıştır. Katılımcılara araştırma sırasında elde edilen verilerin sadece bu araştırmada kullanılacağı, herhangi bir kimlik bilgisinin verilmeyeceği ifade edilerek gönüllü katılım formu imzalamaları sağlanmıştır. Odak grup çalışması araştırmacılar tarafından bizzat gerçekleştirilmiştir. Odak grup görüşmesi, katılımcılardan yazılı izin alınarak kayıt altına alınmış ve odak grup çalışması 1 saat 3 dakika 8 saniye sürmüştür. Ancak sekiz öğretmenden odak grup görüssmesi yoluyla toplanan verinin analizi sürecinde veri doygunluğuna ulaşılmamış olduğu görülmüştür. Bu gerekçeyle odak grup görüşmesi sonrasında ilave bir onbir öğretmen ile yarı yapılandırılmış görüşme formu kullanılmak suretiyle yüzyüze görüşmeler gerçekleştirilmiştir. Araştırmanın son aşamasında da elde edilen ses kayıtlarından elde edilen döküm, analiz edilmek üzere hazır duruma getirilmiştir.

\section{Verilerin Analizi}

Nitel verinin analizinde içerik analizi yöntemi kullanılmıştır. Katılımcıların okullarda adil olmayan yönetsel uygulamalara ve yine adil olmayan bu uygulamalar karşısındaki davranışlara ilişkin görüşleri, alan yazınla uyumlu olarak önceden belirlenmiş temalara dayalı olarak analiz edilmiştir. Bu süreçte katılımcı görüşleri okunmuş, görüşme verileri düzenlenmiş, anlamlı veri birimleri saptanmış ve veriler kodlanmıştır. Bununla birlikte taslak temalar belirlenmiş, taslak temalara göre kodlar düzenlenmiş, taslak tema ve kodlara göre veriler düzenlenmiştir. Benzer şekilde taslak temalar kontrol edilerek kesinleştirilmiş, temalar arasındaki ilişki belirlenmiş, temalar araştırma soruları altında düzenlenmiş, kodlara ve veriler temalara göre betimlenmiş, doğrudan alıntı cümlelerine yer verilmiş, örneklendirilmiş ve görsel hale getirilmiştir. Öğretmenlerin okullardaki adalet uygulamalarına karşı görüşleri, belirli kodların oluşturulmasına imkan verecek biçimde düzenlenmiş, birbirine benzer kodlar, ilgili temanın bulunduğu sütuna yerleştirilmiştir. 


\section{Nitel Araştırmada Geçerlik ve Güvenirlik}

Nitel araştırmalarda iç geçerliliğin sağlanması için araştırmacıdan verinin toplanması, verinin analiz edilmesi ile yorumlanması aşamasında tutarlı olması ve bu tutarlılığın nasıl sağlandığının açiklanması beklenmektedir. İç geçerliği sağlamak için ise uzun süreli etkileşim, derinlik odaklı veri toplama, çeşitleme, uzman inceleme, katılımc teyidi gibi yöntemler kullanılmaktadır (Yıldırım ve Şimşek, 2016; s.277). Bu araştırmada iç geçerliliğin sağlanması için yapılan görüşmeler, katılımcıların okullardaki örgütsel adaleti tüm boyutlarıyla ele almalarına imkan sağlayacak derinlikte yürütülmüştür. Görüşme yapılan katılımcılar, görüşme yapılmadan önce örgütsel adalet konusunda bilgilendirilmişlerdir. Bu şekilde öğretmenlerin okullardaki örgütsel adalete ilişkin görüşlerini alan yazınla tutarlı olmasına olanak sağlayacak şekilde açıklayabilmeleri amaçlanmıştır. Elde edilen verilerin ilgili alan yazınla tutarlığı sürekli kontrol edilerek, verilerin inandırıcılığ 1 sağlanmaya çalışılmıştır. Araştırmada örgütsel adalet uygulamalarına ilişkin görüşlerin çeşitlendirilmesi için katılımcılar farklı okullardan seçilmiştir. Katılımcılara ait farklı bakış açılarının belirlenebilmesi için etkileşimli odak grup görüşmesi yapılmıştır. Ancak sekiz öğretmenden odak grup görüşmesi yoluyla toplanan verinin analizi sürecinde veri doygunluğuna ulaşılmamış olduğu görülmüştür. Bu gerekçeyle odak grup görüşmesi sonrasında ilave bir onbir öğretmen ile yarı yapılandırılmış görüşme formu kullanılmak suretiyle yüzyüze görüşmeler gerçekleştirilmiştir. İç geçerliliğin sağlanması amaciyla bir başka yöntem olarak uzman görüşüne başvurma yoluna gidilmiştir. Araştırmada yarı yapılandırılmış görüşme formunun oluşturulmasinda, verinin analiz edilmesinde ve yorumlanmasinda da alan uzmanlarından geribildirimler alınmıştır. Araştırmacı yanlılığının azaltılması, veri inandırıcılığının arttırılması amacıyla bulgular birebir alıntılarla desteklenmiştir.

Nitel araştırmada dış geçerliğinin sağlanmasına yönelik yöntemlerden biri, araştırmacının kendisine ait yorum katmadan, verinin özüne bağlı kalarak araştırmanın sonuçlarını aktardığı yöntem olan "ayrıntılı betimleme"dir (Yıldırım ve Şimşek, 2016, s. 282). Bu çalışmada, araştırmanın bütün aşamaları ayrıntılı şekilde anlatılmış, yarı yapılandırılmış görüşme formunun hazırlanması, verinin toplanması, analiz edilmesi ve yorumlanması süreci anlaşılır ve ayrıntılı şekilde belirtilmiştir. Araştırmacının araştırma 
bulgularına dayalı olarak yaptığı yorumlar, doğrudan alıntı cümleleriyle desteklenmiştir. Ayrıntılı betimleme yöntemi ile okuyucu araştırma verilerin elde edildiği ortamı zihninde canlandırabilir ve kendi ortamına ilişkin olması muhtemel sonuçları daha kolay tahmin edebilir. Ayrıca verinin ayrıntılı betimlenmesi, okuyucuya kendi sonucuna ulaşma ve sonuç hakkında yorumda bulunma olanağı verir.

Araştırmada odak grup görüşmesinden elde edilen verinin güvenirlik analizi yapılmıştır. Temalar altında toplanan kodlar, farklı alan uzmanları tarafından incelenmiştir. Uzman incelemesi sonucunda uzmanlar arasındaki görüş birliği ve görüş ayrıllğı belirlenerek uyuşum yüzdesi hesaplanmıştır. Alanyazında kodlama güvenilirliği diye de isimlendirilen bu süreçte, Miles ve Huberman (1994) tarafından önerilen uzlaşma yüzdesi formülü (UY= görüş birliği (36) / (görüş birliği (36) + görüş ayrılığ1 (3) ) *100) kullanılmıştır. Araştırmacı ve uzmanlar arasındaki genel uyuşum yüzdesi \%92 olarak hesaplanmıştır. Nitekim Miles ve Huberman (1994)'a göre uzlaşma yüzdesinin \% 70 'in üzerinde olması güvenirliğe işaret eden bir durumdur (Miles ve Huberman, 1994).

\section{Araştırmacıların Rolü}

Nitel desenle yürütülen bu çalışmada, araştırmacılar gereksiz sınıflandırma ve akıcı olmayan yorumlardan kaçınmışlardır. Çalışmada hoşgörü ve işbirliği araştırmacılar arasında temel davranış olarak ele alınmıştır. Araştırmacılar, her türlü şartlandırma ve dayatmadan uzak kalan bir çalışma gerçekleştirmişlerdir. Bu da katılımcılara kendilerini ifade etme olanağı sağlayarak araştırmaya zengin bir içerik sunma yönünde katkı sağlamıştır. Araştırmacı ve katılımcı arasındaki çift yönlü etkileşim çok sesliliğin oluşumuna katkı sağlamıştır. Araştırmacılar, katılımcılarla bizzat görüşme gerçekleştirmiştir.

\section{Etik Konular}

Araştırmanın güvenirliği için veriler ve ulaşılan sonuçlar çarpitılmadan, araştırmaya dayanarak üretilen veriler düzenlenerek doğru biçimde sunulmuştur. Disiplinsiz araştırmaların yol açtığı dürüst hatalar ile bilerek ve isteyerek yanıltma niyeti olan uydurma, saptırma ve aşırma davranışları olan bilimsel yalancılıktan araştırma süresince uzak durulmuştur. 
Makale, daha önceden herhangi bir yerde yayımlanmamış, dilimleme özelliği taşımayan ve bilimsel bir birikime sahip çalışmadır. Çalışmada destek alınan kişi ve kurumlar belirtilmiştir. Yazarlık hakkını elde eden kişiler (i) araştırmanın tasarlanması, verilerin toplanması ve çözümlenmesi, bulguların yorumlanması, (ii) çalışmanın yazılması ve bilimsel açıdan incelenmesi, (iii) çalışmanın son halinin onaylanmasında katkı sağlamışlardır. Araştırma süresince çeşitli nedenlerle verilerin ilgi çekici hale getirilmesi ve sonuçların daha çarpıcı ve tutarlı görünmesi için üzerinde oynanarak düzeltme yapılması davranışından uzak durulmuştur. Yine bu araştırmada çalışılan konu ile ilgili olarak başka araştırmacılar tarafından üretilen yayınlar incelenerek elde edilen bulgular ve sonuçlar kullanılmıştır.

Bu araştırma, Hacettepe Üniversitesi Senatosu Etik Komisyonu kurulunun 17/12/2019 tarihli ve 35853172-300 sayıl kararı ile alınan izinle yürütülmüştür.

Odak grup görüşmesi, görüşmeye katılmaya gönüllü olduğunu belirten sekiz katılımcı öğretmen ile gerçekleştirilmiştir. Ancak sekiz öğretmenden odak grup görüşmesi yoluyla toplanan verinin analizi sürecinde veri doygunluğuna ulaşılmamış olduğu görülmüştür. Bu gerekçeyle odak grup görüşmesi sonrasında ilave bir onbir öğretmen ile yarı yapılandırılmış görüşme formu kullanılmak suretiyle yüzyüze görüşmeler yapılmıştır. Katılımcı öğretmenlere araştırmada elde edilen verinin sadece bu çalışmada kullanılacağı, herhangi bir kimlik bilgisinin verilmeyeceği belirtilerek gönüllü katılım formu imzalamaları sağlanmıştır.

\section{Bulgular}

Araştırma sürecinde elde edilen bulgular okullarda adil olmayan uygulamalar, adil olmayan uygulamalar karşısında öğretmen duyguları ve adil olmayan uygulamalar karşısında öğretmen davranışları olmak üzere üç tema altında katılımcıların görüşleri ile birlikte sunulmuştur.

\section{Okullarda Adil Olmayan Uygulamalara Yönelik Bulgular}

Okullarda adil olmayan uygulamalara yönelik bulgulara ilişkin tema, kod ve frekans değerleri Tablo 2'de sunulmaktadır: 
Tablo 2. Okullarda Adil Olmayan Uygulamalara Yönelik Bulgular

\begin{tabular}{lcc}
\hline Kod & Tema & $f$ \\
\hline Yönetmelik maddelerinin uygulanmasının genele yayılması & & 5 \\
İdareye yakın olana yönelik kayırmacı davranış & Dağıtım Adaleti & 3 \\
İlim açısından tanınan imkânların fazla olmaması & & 1 \\
\hline Tutarsızlık & Süreç Adaleti & 6 \\
Yönetmelik dışı uygulama & & 3 \\
Haksızlık & & 7 \\
\hline Zayıf olana yaptırım uygulanması & Etkileşimsel Adalet & 1 \\
Yapılan işten dolayı takdir görmeme & 3 \\
Ders programlarının kötü yapılması & & 2 \\
Kabul edilmeyen görev için ortamın cehennem edilmesi & \\
Haksızlı̆̆ı ortaya çıkaran öğretmenin mağdur edilmesi & & 3 \\
\hline
\end{tabular}

Tablo 2'den izlenildiği üzere okullarda adil olmayan uygulamalara yönelik katılımcı görüşleri dağıtım adaleti, süreç adaleti ve etkileşimsel adalet olmak üzere üç tema altında toplanmıştır. Dağıtım adaleti teması altında yer alan kodlardan biri yönetmelik maddelerinin uygulanmastnin genele yayılması şeklindedir. Bu kapsamda görüş bildiren katılımcllardan biri aşağıdaki şekilde paylaşımda bulunmuştur:

...Zayıf olanın, garibanın ücra yerlerde çalıştı̆̆ı sistemi değiştirip uygulamak lazım. Sistem kuruluyorsa herkese kurulmall. Bunun genele tabana yayllması gerektiğini düşünüyorum (Ö6).

Dağıtım adaleti teması altında yer alan bir diğer kod ise idareye yakın olana yönelik kayırmacı davranıştır. Bu yönde görüş bildiren katılımcı aşağıdaki gibi paylaşımda bulunmuştur:

...Benim en çok somut ifade etmek istediğim şey, idarecilerle yakm olan kayırmacı politikalardan dolayı okulda daha rahat ediyor. Bu benim çok onuruma dokunan bir şey insan olarak (Ö7).

Dağıtım adaleti teması alında yer alan kodlardan bir diğeri ise ilim açısından tanınan imkânların fazla olmamasıdır. Bu yönde görüş bildiren bir katılımCl görüşlerini şu şekilde ifade etmiştir:

...Adalet duygusunun kırıldığın görmek bizde ciddi anlamda hayal kırıklğıına sebep oluyor. Burada bir çözüm yok. Kimle konuşacağız, nasıl çözeceğiz. Kiminle işbirliği yaparak çözeceğiz. Bu kadar sürede çalısma hayatımın içinde şu karara vardım, ortamımız kü̧̈ük olduğu için maalesef keşke öyle olmasaydı ilim açısından başka açlardan bize tanınan imkânlar fazla olsaydı düşünce yapımız da basit oluyor ve birbirimizi çok kolay harcayabiliyoruz (Ö7). 
Tablo 2'de görüldüğü gibi okullarda adil olmayan uygulamalara yönelik olarak katılımcı görüşlerinin toplandığı bir diğer tema süreç adaletidir. Süreç adaleti teması altında yer alan kodlardan biri tutarsızlıktır. Bu kodla ilgili katılımcılardan biri şu şekilde görüş belirtmiştir:

... İdarecim bana "çocuğunu bir sonraki gün de getirecek misin" diye sordu. Hâlbuki bunu sorarken başka bir idareci arkadaşın çocuğu hemen hemen dönemin içinde her zaman okuldaydl, geliyordu- gidiyordu. O daha büyük bir çocuk, sürekli okulda öğrencilerin içinde falan. Gün içinde okulda okulun bir bireyi gibiydi. Bu beni açıkçası üzmüştü. Ben uygulamaya baktım söyleme baktım, tutarsız bir davranı̧ (Ö1).

Süreç adaleti teması altında yer alan kodların diğeri ise yönetmelik dışı uygulamalara ilişkindir. Bu koda ilişkin bir katılımcının görüşü şu şekildedir:

...Yetiştirme kursu ile ilgili olarak hocamın yaşadığ sıkıntının birebir aynısın ben de yaşadım. İdare tarafindan yaşadım. İdarecilerin kendilerine biraz daha toleranslı davrandığını hatta yönetmeliklerin dışına çıkıldığına şahit oldum (Ö3).

Süreç adaleti teması altında yer alan kodlardan bir diğeri ise haksızlıktır. Bu koda ilişkin katılımcılaran biri görüşlerini şu şekilde özetlemiştir:

... İnsanın bulunduğu yerde sorun da oluyor. Benim canımı en çok yakan bu adaletsizlikler olmuştur. Kişisel haksızlıklara da uğradım çeoremde haksızlklara uğrayanlarn da gördüm (Ö7).

Tablo 2'de belirtildiği gibi okullarda adil olmayan uygulamalara yönelik olarak katılımcı görüşlerinin toplandığı bir diğer tema etkileşimsel adalettir. Katılımcıların etkileşimsel adalet teması altında belirttiği kodlardan biri zayıf olana yaptırım uygulanmasıdır. Bu kapsamda katılımclardan biri görüşü şu şekilde ifade etmiştir:

...Bireysellikten ziyade örgütleri sistem içine oturtup yönetmek lazım. Zayıf olanın garibanın ücra yerlerde çalıştı̆̆ı sistemi değiştirip uygulamak lazım (Ö6).

Etkileşimsel adalet teması altında katılımclların belirttiği kodlardan bir diğeri yapılan işten dolayı takdir görmemedir. Bu kapsamda görüş bildiren katılımcılardan biri şu şekilde paylaşımda bulunmuştur:

...Hangi ortamda olursa olsun insan birileriyle yakmliğından dolayı level atlamamah yaptığı işten dolayı takdir edilmeli. Görev verilirken sesi çıkmayana veya itiraz etmeyene ya da daha halim selim olana veyahut ödül verilirken daha çok sesi çıkana, idarecilere yakın olana takdir verilmesi üzücü oluyor (Ö7). 
Etkileşimsel adalet teması altında katılımcların belirttiği kodlardan bir diğeri ise ders programlarmmı kötü yapılmasıdır. Bu konuda katılımcılardan biri görüşünü şu şekilde özetlemiştir:

... Bize verdiler bu görevi biz de kabul etmedik, bu bizim görevimiz değil bu işle ilgili bir ekip kurdunuz kurduğunuz ekip çalısmalı dedik. Biz bunu kabul etmedik diye çok ciddi tavır geliştirdi idarecilerimiz bize. Sonra aramız gerçekten ciddi gerildi. Programlarımızı kötü yaptılar (Ö7).

Etkileşimsel adalet teması altında katılımcılar tarafından belirtilen diğer bir kod kabul edilmeyen görev için ortamm cehennem edilmesidir. Bu koda ilişkin olarak bir katılımcının görüşü şu şekildedir:

...Yani biz çözemiyoruz meseleyi. Kötü oluyoruz ve kötü de hissediyoruz. Nihayetinde o ortamdan tayin alıp gitmek zorunlu oluyor. Kaçıyoruz, kaçmak zorundayız çünkü orayı bize cehennem ediyorlar (Ö7).

Etkileşimsel adalet teması altında katılımclar tarafından belirtilen bir başka kod haksızlı̆̆ ortaya çıkaran öğretmenin mağdur edilmesidir. Bu koda ilişkin olarak katılımclardan birinin görüşü şu şekildedir:

...Hak arama mücadelesine girdiğinizde ciddi sorunlar yaşıyorsunuz, herkesin ortak sıkıntısı bunu çözemiyorsunuz. Konuştuğunuz insanlar haksızlğ̆ı ortaya çıkaran ya da destekleyen insanlar, nihayetinde mağdur oluyoruz (Ö7).

\section{Adil Olmayan Uygulamalar Karşısında Öğretmen Duyguları}

Adil olmayan uygulamalar karşısında öğretmen duygularına yönelik bulgulara ilişkin temalar, temalara ait kodlar ve frekans değerleri Tablo 3'te sunulmuştur.

Tablo 3. Adil Olmayan Uygulamalar Karşısında Öğretmen Duygularnna Yönelik Bulgular

\begin{tabular}{lll}
\hline Kod & Tema & $f$ \\
\hline Üzüntü & & 9 \\
Çaresizlik & & 2 \\
Mutsuzluk & Olumsuz Duygular & 5 \\
Tedirginlik & & 2 \\
Hayal kırıklğı & & 7 \\
Siknntı & & 4 \\
\hline Kamçlanmak & Duygusal Red & 10 \\
\hline
\end{tabular}

Tablo 3'te görüldüğü gibi okullarda adil olmayan uygulamalar karşısında öğretmen duygularına yönelik katılımcı görüşleri olumsuz duygular ve 
duygusal red olmak üzere iki tema altında toplanmıştır. Olumsuz duygular teması altında yer alan kodlardan biri üzüntü şeklindedir. Bu kapsamda görüş bildiren katılımcılardan birinin görüşü şu şekildedir:

Muhakkak üzülüyorsunuz, insanoğlu duygusal bir varlıksınız. Öğretmenlik bir meslek değil apayrı bir şey bence. Sinıfa girdiğiniz zaman kendini apayrı bir dünyada görüyorsunuz gelecekte gibi (Ö6).

Olumsuz duygular teması altında yer alan bir başka kod çaresizliktir. Bu yönde görüş bildiren katılıma görüşlerni şu şekilde ifade etmiştir:

Elbette gitmek istediğim böyle bir an oldu, ama böyle bir eylem içine giremedim. Yapabildiğim tek şey yeri geldiği zaman konuşmak oldu. Yani kendimi ifade etmeye çalıştım (Ö1).

Olumsuz duygular teması altında yer alan diğer bir kod mutsuzluk şeklindedir. Bu kod ile ilgili bir katılımcının görüşleri şu şekildedir:

Daha sonrasinda biz mutsuz oluyoruz. Derslere mutsuz girip çıkıoruz, o tavm görmek istemiyoruz ve nihayetinde veriminiz düşüyor (Ö7).

Olumsuz duygular teması altında ortaya çıkan bir başka kod tedirginlik şeklindedir. Bu kodla ilgili olarak katılımcılardan biri görüşlerini şu şekilde özetlemiştir:

Adalet meselesi bozulduğu zaman ortam karmaşıklaşıyor ya o bizi gerçekten tedirgin ediyor. Bugün böyle yarm acaba ne sorun çkacak diye tedirgin olabiliyorsunuz (Ö6).

Olumsuz duygular teması altında yer alan kodlardan bir diğeri hayal klrıklı̆̆ıdır. Katılımcılardan birinin bu koda ilişkin belirttiği ifade şu şekildedir:

...Adalet duygusunun kırıldığın görmek bizde ciddi anlamda hayal kırıklğ̆ına sebep oluyor. Burada bir çözüm yok. Kimle konuşacağız, nasıl çözeceğiz..."(Ö3) şeklindedir.

Olumsuz duygular teması altında yer alan bir diğer kod ise sıkıntıdır. Bu kod ile ilgili olarak bir katılımc şu şekilde görüş belirtmiştir: (Ö3).

... Bir şey yapamamanın verdiği sıkıntı. Elimizden bir şey gelmemesinin sıkıntısı

Tablo 3'ten izlenildiği üzere okullarda adil olmayan uygulamalar karşısında öğretmen duygularına yönelik katılımcı görüşlerinden oluşan diğer bir tema duygusal rede ilişkindir. Duygusal red teması altında yer alan kod kamçılanmak şeklindedir. Bu koda ilişkin katılımcılardan birinin görüşü şu şekildedir: 
... İş doyumu noktasında elbette bir kırılma noktası yaşıyorsunuz ama rotanızı başka yöne çeviriyorsunuz. Elbette etkileniyorsunuz ama bunlar sizi kamçllyor. Daha adil insanlar yetiştireceğim diye kamçılanıyorsunuz (Ö6).

\section{Adil Olmayan Uygulamalar Karşısında Öğretmen Davranışları}

Adil olmayan uygulamalar karşısında öğretmen davranışlarına yönelik bulgulara ait temalar, temalara ait kodlar ve frekans değerleri Tablo 4 'te sunulmuştur:

Tablo 4. Adil Olmayan Uygulamalar Karşısında Öğretmen Davranışlarına Yönelik Bulgular

\begin{tabular}{lll}
\hline Kod & Tema & $f$ \\
\hline İstifa etmek & İşten Ayrilma & 1 \\
Tayin istemek & & 5 \\
\hline Kendini savunmak & & 5 \\
İtiraz etmek & Muhalefet Etme & 6 \\
Anında tepkide bulunmak & & 4 \\
Yüz yüze görüşmek & & 5 \\
İlkesel tavir geliştirmek & & 1 \\
Konuşmak & & 7 \\
Hak aramak & Bilgi Uçurma & 6 \\
Direnmek & Sadakat Gösterme & 2 \\
\hline Üst merci ile iletişime geçmek & & 2 \\
\hline Kendi davranışlarını düzeltmeye çalışmak & 5 \\
Sabretmek & & 3 \\
\hline Susmak & & 7 \\
Kendini ortamdan soyutlamak & 3 \\
Yok saymak & Kayıtsız Kalma & 3 \\
Görmezden gelmek & & 6 \\
Muhatap olmamak & & 5 \\
Uzak durmak & & 3 \\
İşi kendi başına yapmaya çalışmak & \\
Beklemek & & 1 \\
\hline
\end{tabular}

Tablo 4'te görüldügü üzere okullarda adil olmayan uygulamalar karşısinda öğretmen davranışlarına yönelik katılımcı görüşleri işten ayrılma, muhalefet etme, bilgi uçurma, sadakat gösterme ve kayıtsız kalma olmak üzere dört tema altında toplanmıştır. İşten ayrılma teması altında yer alan kodlardan biri istifa etmek şeklindedir. Bu kapsamda katılımcılardan birinin görüşü şu şekildedir:

...Mesleğin başlarında bu norm kadro olayı yeni çıktı̆̆ında okulda 3 tane öğretmen boş duruyordu, torpilli gelmişler. Onlar okulda durdu, beni bir dağ köyüne 
gönderdiler. Ben de istifa dilekçesini cebime koydum İl Milli Ĕ̆itim Müdürlüğ̈̈ne gittim (Ö8).

İşten ayrılma teması altında bir diğer kod tayin istemek şeklindedir. Bu koda ilişkin bir katılımcı şu şekilde görüş belirtmiştir:

...E Ĕ̆er çözüme ulaşma ihtimalim yoksa hiçbir şey söylemem. Olaylarn daha beter büyütmeye gerek yok. Mümkün olduğu kadar kendimi ortamdan soyutlamaya çalışırdım. Tayin isteyebilirdim. Böyle sürekli devam eden bir ortamda bulunmayı istemem (Ö4).

Tablo 4'te izlenildiği üzere okullarda adil olmayan uygulamalar karşısında öğretmen davranışlarına yönelik katılımcı görüşlerinin toplandığı bir diğer tema muhalefet etmedir. Muhalefet etme teması altında yer alan kodlardan biri kendini savunmak şeklindedir. Bu koda ilişkin katılımcılardan biri görüşünü şu şekilde ifade etmiştir:

Görevlerinizi ve haklarnnzı biliyorsanız kendinizi savunabiliyorsunuz (Ö6).

Muhalefet etme teması altında diğer bir kod itiraz etmektir. Bu koda ilişkin katılımclardan biri görüşünü şu şekilde özetlemiştir:

...Daha önce çalş̧ı̆̆ım bir ilçeye yeni bir kaymakam gelmiş velilere ev ziyareti yapılmasın istedi. Hiçbir veliye ziyarete gitmediğimi söyleyince gerekçe sordu, ek ders ve resmi görev yazısı istedim. Baktım hakllar, sona da uğraşmadılar benimle çünkü benim görevim derse girmek (Ö6).

Muhalefet etme teması altındaki kodlardan diğeri anında tepkide bulunmak şeklindedir. Bu koda ilişkin bir katılımcının paylaştığı görüş şu şekildedir:

...Bazı problemlerde ise anında tepkide bulunmak gerekli..." (Ö7) şeklindedir. Muhalefet etme teması altında bir diğer kod yüz yüze görüşmektir. Bu koda ilişkin katılimclardan biri“...Çoğunlukla biraz bekliyorum bu benim kişisel tavrm, sonra gidip görüşmeyi seçiyorum (Ö7).

Muhalefet etme teması altında yer alan diğer bir kod ilkesel tavır geliştirmek şeklindedir. Bu koda ilişkin katılımcılardan birinin görüşü şu şekildedir:

...Asıl sorunumuz ilkesel tavır geliştirmemekten kaynakl. Nihayetinde hepimiz ekip halinde çalı̧malıyız, bireyler üzerinden hareketle iş yürütülmüyor, adalet herkesi kapsayıcı olmalı (Ö7).

Muhalefet etme teması altında yer alan kodlardan bir diğeri konuşmak şeklindedir. Bu koda ilişkin bir katılımcı şu şekilde görüş belirtmiştir:

Bazen çözümü konuşmayla olacak sorunlar mutlaka sorumlu kişilerle konuşmuşuzdur (Ö3). 
Muhalefet etme teması altında belirtilen kodlardan bir diğeri hak aramaktır. Bu koda ilişkin katılımcılardan birinin görüşü şu şekildedir:

Çözülmüştür, çzülmemiştir. En azından biz söyleyip hakkımızı aradık (Ö3).

Muhalefet etme teması altında ifade edilen kodlardan biri direnmek şeklindedir. Bu koda ilişkin bir katılımcı görüşlerini şu şekilde ifade etmiştir:

Hakkımı arardım, eğer gerçekten hakliysam ve hakkımsa eğer, ben onun arkasında direnirdim. Yani hiçbir şekilde tayin isteyip ayrılmazdım okulumdan (Ö2).

Tablo 4'te belirtildiği üzere okullarda adil olmayan uygulamalar karş1sında öğretmen davranışlarına ilişkin bir diğer tema bilgi uçurmadır. Bilgi uçurma temasına ilişkin ifade edilen kod üst merci ile iletişime geçmektir. Bu koda ilişkin bir katılımcının görüşü şu şekildedir:

...Bu şekilde çözümlenmeyenlere bir üst mercide sorun nerede çözülüyorsa mutlaka orayla iletişime geçilmiştir (Ö6).

Tablo 4'te görüldüğü gibi okullarda adil olmayan uygulamalar karşısında öğretmen davranışlarına ilişkin temalardan bir diğeri sadakat gösterme şeklindedir. Sadakat gösterme teması altında ifade edilen kod kendi davranışlarım düzeltmeye çalısmak şeklindedir. Bu koda ilişkin bir katılımcı şu şekilde görüş belirtmiştir:

... Ĕ̆ger ben bu lafi hak ettiysem kendime söylerim kendimi düzelteyim diye (Ö5).

Sadakat gösterme teması altında ifade edilen kodlardan bir diğeri ise sabretmektir. Bu koda ilişkin katılımcılardan birinin görüşü şöyledir:

... Eğer çözüme ulaşma ihtimalim yoksa hiçbir şey söylemem (Ö4).

Tablo 4'te izlenildiği gibi okullarda adil olmayan uygulamalar karşısında öğretmen davranışlarına ilişkin temalardan bir diğeri kayıtsız kalmadır. Kayıtsız kalma temasına ilişkin kodlardan biri susmak şeklindedir. Bu koda ilişkin katılımcılardan biri görüşlerini şu şekilde özetlemiştir:

Öğretmen olarak gücümüzün yetmediğini bir şekilde sineye çektĭgimiz söyleyeyim (Ö3).

Kayitsız kalma temasına ilişkin kodlardan bir diğeri kendini ortamdan soyutlamak şeklindedir. Bu koda ilşkin katılımcılardan birinin belirttiği görüş şu şekildedir:

...Olayları daha beter büyütmeye gerek yok. Mümkün olduğu kadar kendimi ortamdan soyutlamaya çalışırdım (Ö4).

Kayıtsız kalma temasına ilişkin bir başka kod yok saymaktır. Bu koda ilişkin katılımcının birinin görüşü şöyledir:

...Isteyemiyorsam da yok sayarm (Ö4). 
Kayıtsız kalma teması adı altında ifade edilen bir başka kod görmezden gelmektir. Bu koda ilişkin bir katılımcının paylaşımı şu şekildedir:

...Stnıftan çıkarım ve gerisini görmemezlikten gelirim (Ö7).

Kayıtsız kalma teması altında yer alan bir başka kod muhatap olmamak şeklindedir. Bu koda ilişkin bir katılımc görüşünü şu şekilde özetlemiştir:

...Veya bir öğretmen arkadaşımsa onunla yapmam gereken bir işi kendi başıma yapmaya çalışıyorum gibi (Ö1).

Kayıtsız kalma teması altında yer alan diğer bir kod uzak durmaktır. Bu koda ilişkin bir katılımcı

...Ĕ̆ger kişinin şahsindan kaynakl bir laf ise o zaman ben orada durmam, imkânım varsa kaçarım onun altında durmam o zaman, imkânım yoksa uzak dururum (Ö5).

Kayıtsız kalma teması altında yer alan kodlardan bir diğeri ise işi kendi başına yapmaya çalışmak şeklindedir. Bu koda ilişkin katılımcılardan birinin görüşü şu şekildedir:

...Örneğin bir laboratuvar malzemesi lazım olur, ben gidip idarecime söylemem, malzemeleri kendim bulmaya çalışırı (Ö4).

Kayıtsız kalma teması altında yer alan diğer kod beklemektir. Bu koda ilişkin bir katılımcı şu şekilde görüş belirtmiştir:

...Ortamlarda haksızlık, adaletsizlik gördü̈̆̈̈̈m zaman biraz bekliyorum açıkçası direkt kişisel tepki vermiyorum. Bu iş nereye gidecek önce onu anlamaya çalışıyorum (Ö7).

\section{Tartışma ve Sonuç}

Okullarda adil olmayan uygulamalara yönelik araştırma bulguları incelendiğinde örgütsel adaletin alt boyutu olan dağıtım adaleti teması altında katılımcı öğretmenlerin yönetmelik maddelerinin uygulanmasının genele yayılması, idareye yakın olana yönelik kayırmacı davranış, ilim açısından tanınan imkânların fazla olmaması şeklinde görüş bildirdikleri görülmektedir. Bunun nedeni öğretmenlerin dağıtım adaleti boyutunda yöneticilerden kararların tarafsız bir şekilde alınmasını ve örgütsel sonuçlar konusunda hakkaniyetli davranılmasını istemeleri olabilir. Bu bulgunun çeşitli araştırmalar tarafından desteklendiği görülmüştür (Hoy ve Tarter, 2004; Folger ve Konovsky, 1989). Her iki araştırma sonucuna göre çalışanlar elde edilen kazanımların adil olarak dağıtıldığı algısına sahip olmayı, örgüte sundukla- 
r1 katkılarla dengeli oranda ödüllendirme davranışı beklemektedir. Bu sonuç, öğretmenlerin dağıtımsal adalet boyutunda örgüte kattığı değer karşısinda hakettiğine inandığı kazancı elde edememesi ile ilgili olabilir.

Okullarda adil olmayan uygulamalara yönelik bir diğer araştırma bulgusu süreç adaletine ilişkindir. Katılımcı öğretmenler süreç adaleti teması altında tutarsızlık, yönetmelik dişı uygulama ve haksızlık kodu altında ifadeler dile getirmiştir. Bunun nedeni öğretmenlerin kararların alındığ 1 sürece ilişkin adil uygulamalar bekliyor olmasından kaynaklanıyor olabilir. Bu araştırma bulgusu, Şahin ve Kavas (2016) tarafından yapılan araştırmada katılımcların yüksek düzeyde süreç adaleti algısına sahip oldukları saptanmıştır. Bu sonuç, öğretmenlerin kazanımlara ilişkin dağıtım kararlarının nasıl alındığına dair yöneticilere güven duyması ile ilgili olabilir.

Okullarda adil olmayan uygulamalara yönelik diğer bir araştırma bulgusu ise etkileşimsel adalet teması altında belirtilen zayıf olana yaptırım uygulanması, yapılan işten dolayı takdir edilmeme, ders programlarının kötü yapılması, kabul edilmeyen görev için ortamın cehennem edilmesi, haksızlığ1 ortaya çıkaran öğretmenin mağdur edilmesi kodlarına ilişkindir. Bu, katılımcı öğretmenlerin yöneticiler tarafından doğru bilgi aktarılmadığı, tam olarak bilgilendirilmedikleri, kararlara ilişkin gerekçe göstermedikleri ile ilgili bir durumun sonucu ile ilgili olabilir. Bu bulguya ilişkin görüş belirten katılımcı öğretmenler, yöneticilerin kendilerine değer vermelerini, sayg1 duymaların istemektedirler. Özer ve Urtekin (2007) tarafından yapılan araştırmada katılımcılar örgütsel adaletin alt boyutu olan etkileşimsel adalet boyutunda olumlu görüş belirtmişlerdir.

Adil olmayan uygulamalar karşısında öğretmen duygularına yönelik araştırma bulgularından biri olumsuz duygular teması altındadır. Olumsuz duygular teması altında katılımcı öğretmenler üzüntü, çaresizlik, mutsuzluk, tedirginlik, hayal kırıklığı, sıkıntı şeklinde görüş belirtmişlerdir. Bu bulgu, katılımcı öğretmenlerin adil olmayan uygulamalar karşısında duygusal anlamda tükenmişliklerinin sonucu olabilir. Budak ve Sürgevil (2005) tarafından yapılan araştırmada katılımcılar örgütsel adalet boyutlarıyla ile ilgili olarak duygusal tükenmişliğe bağlı olarak öfke, kızgınlık gibi duygular yaşadıklarını ifade etmişlerdir. Adil olmayan uygulamalar karşısında öğretmen duygularına yönelik araştırma bulgularından bir diğeri duygusal red teması altındadır. Duygusal red teması altında katılımcı öğretmenler kamçılanmak kodu altında görüş belirtmiştir. Bu sonuç, katılımcı öğretmen- 
lerin örgütsel bağlllıkları ile ilgili olabilir. Bu araştırma bulgusu, Demir ve Öztürk (2011) tarafından yapılan örgütsel bağlılığa ilişkin araştırma sonuçları ile örtüşmektedir.

Adil olmayan uygulamalar karşısında öğretmen davranışlarına yönelik araştırma bulgularından biri işten ayrılma teması altındadır. İşten ayrılma teması altında katılımcı öğretmenler istifa etmek, tayin istemek kodları altında görüss belirtmişlerdir. Bu durumun nedeni, olumsuz örgütsel adalet algısına sahip katılımcı öğretmenlerin iş doyumlarının düşmesi sonucu işten ayrılma niyetlerinin artması olabilir. Gürpınar (2006), Örücü ve Özafşarlıŏlu (2013) tarafından yapılan araştırmalarda elde edilen örgütsel adalet algısı ile işten ayrılma niyeti arasında negatif yönlü ilişki olduğu sonucuna ulaşılmıştır.

Adil olmayan uygulamalar karşısında öğretmen davranışlarına yönelik araştırma bulgularından bir diğeri muhalefet etme teması altındadır. Muhalefet etme teması altında katılımcı ögretmenler kendini savunmak, itiraz etmek, anında tepkide bulunmak, yüz yüze görüşmek, ilkesel tavır geliştirmek, konuşmak, hak aramak, direnmek kodları ile görüşlerini belirtmişlerdir. Bu durum örgüt çalışanlarının birbirleri ile iletişim halinde olmak ve örgüt içinde alınan kararlara ilişkin duygu ve düşüncelerini belirtmek istemeleri ile ilgili olabilir. Bu bulgunun çeşitli araştırmalar tarafından desteklendiği görülmektedir (Dağlı ve Ağalday, 2014; Kavak ve Kaygın, 2018). Araştırma sonuçlarına göre muhalefet etme davranışının nedenleri olarak öğretmenleri ilgilendiren konularla ilgili alınan kararlarda öğretmen görüşlerinin alınmaması, etik dışı uygulamalar, örgütsel kaynakların elde edilmesi ve dağıtılmasında adil davranılmaması sonucuna ulaşılmıştır.

Adil olmayan uygulamalar karşısında öğretmen davranışlarına yönelik bir başka araştırma bulgusu bilgi uçurma teması altında yer almaktadır. Katılımcı öğretmenler bilgi uçurma teması altında üst merci ile iletişime geçmek kodu altında görüş belirtmişlerdir. Bu durumun nedeni, örgüt çallşanlarının örgüt içindeki uygulamalara yönelik alınan etik ve yasaya aykırı kararları ilgililere bildirerek yanlış olanın düzeltilmesini istemeleri olabilir. Nart ve Yürür (2016) tarafından yürütülen ve örgütsel adalet algısının bilgi uçurma davranışını etkilediği ifade edimiştir.

Adil olmayan uygulamalar karşısında öğretmen davranışlarına yönelik araştırma bulgularından bir diğeri sadakat gösterme teması altındadır. Sadakat teması altında katılımcı öğretmenler kendi davranışlarını düzeltmeye 
çalışmak, sabretmek kodu altında görüş belirtmiştir. Bu durumun nedeni çalışanın örgütsel bağlılığının sonucu olabilir. Bu bulgu Koç (2009) tarafından yapılan araştırmada çalışanların adil olmayan uygulamalar karşısında sabretme davranışları sergiledikleri belirtilmiştir. Adil olmayan uygulamalar karşısında öğretmen davranışlarına yönelik araştırma bulgularından bir diğeri kayıtsız kalma teması altında yer almaktadır. Kayıtsız kalma teması altında öğretmenler susmak, kendini ortamdan soyutlamak, yok saymak, görmezden gelmek, muhatap olmamak, uzak durmak, işi kendi başına yapmaya çalışmak, beklemek kodları altında görüşlerini ifade etmişlerdir. Bu durum çalışanlarda iş doyumunun azalmasının nedeni olabilir. Şimşek ve Aslan (2012) tarafından yapılan araştırmada, iş doyumu düşen çalışanın kayıtsız kalma davranışı sergilediği ifade edilmiştir.

$\mathrm{Bu}$ araştırmada öğretmen görüşleri doğrultusunda öğretmenlerinin okullardaki adalet uygulamalarına ilişkin görüşlerinin neler olduğu keşfedilmeye çalışılmıştır. Bu araştırmadan keşfedilen temel bulgu, öğretmenlerin örgütsel adalet uygulamalarında benzer görüşlere sahip olduğudur. Adil olmayan uygulamalar karşısında öğretmen davranışları ise çeşitlilik göstermektedir. Okullarda adil olmayan uygulamalara yönelik öğretmen görüşleri dağıtım adaleti, süreç adaleti ve etkileşimsel adalet boyutlarında sınıflanmıştır. Adil olmayan uygulamalar karşısında öğretmen duyguları olumsuz duygular ve duygusal red boyutlarında sinıflanmıştır. Adil olmayan uygulamalar karşısında öğretmen davranışları işten ayrılma, muhalefet etme, bilgi uçurma, sadakat, kayıtsız kalma boyutlarında sınıflanmıştır. Bu bulgular ışığında yöneticilerin örgütte alınan karar alma süreçlerinde öğretmen görüşlerini alması, öğretmenlerin karar verme sürecinde kullanılan yöntemler hakkında zamanında ve doğru şekilde bilgilendirilmesi sürece yönelik uygulamaların öğretmenler tarafından adil olarak algılanmasına katkı sağlayabilir. Muhalefet etme boyutunda öğretmenlerin ya da örgüt çalışanlarının düşüncelerini ifade etmeleri için uygun ortamlar oluşturulması, desteklenmesi demokratik yaşam temelinde örgütsel iyiliğe katkıda bulunabilir. 


\title{
EXTENDED ABSTRACT
}

\section{Examination Of Teacher Experiences Regarding Organizational Justice In Schools}

\author{
Nuray Özge Sağbaş - Murat Özdemir \\ Ministry of National Education, Hacettepe University
}

When the research and statistical data conducted in recent years are examined, it is seen that teachers request to be appointed either voluntarily or on an excuse and change the places where they work. For instance, in 20182019 academic year, it is revealed with statistical data that approximately $15 \%$ of teachers working in public schools across the country have changed their places [Ministry of National Education, 2019]. There may be several reasons why teachers want to leave their schools. One of these reasons is teachers' perceptions of justice. Research emphasizes that teachers with low perception of justice show behavior of exit due to organizational justice (Hirschman, 1970; Tulunay Ateş and Önder, 2017; Uysal, 2014). According to Rusbult, Zembrodt and Gunn (1982), the behavior of exit refers to the situation of seeking a new job or switching to another job. Another reaction of the teachers with low perception of organizational justice is the behavior of voice. Sometimes, teachers give priority to the needs of the organization they work before their own needs due to the low perception of justice and work overtime. In loyalty dimension, teachers wait patiently, hoping for better conditions (Grima and Glaymann, 2012; Hirschman, 1970; Özsoy Özmen, 2017). In addition to exit, loyalty, and voice, teachers whose perceptions of justice decreasing sometimes display passive behavior by neglecting problems and events in the organization (Farrell, 1983; Özsoy Özmen, 2017; Withey and Cooper, 1989). As stated, the perceptions of teachers regarding organizational justice related to the working environment are effective in displaying their behavior of exit, voice, loyalty and neglect (Çelik, 1987; Eklund, 2009; Hirschman, 1994; Leck and Saunders, 1992). It is seen that the effects of organizational justice on some organizational outcomes are questioned in literature reviews that focused on educational organizations. For instance, in the study conducted by Şahin and Kavas (2016), it was determined that teachers had a high level of organizational justice perception. In 
his study, Ertürk (2003) concluded that organizational communication and organizational justice perception affected the formation of organizational identity in employees. In the study conducted by Lee and Wilbur (1985) it was concluded that there was a statistically significant and positive relation between organizational justice and job satisfaction, and the sub-dimensions of organizational justice were significant predictors of job satisfaction. In another study conducted by Kavak and Kaygin (2018), it was determined that there was a significant relation between organizational justice practices and behavior of voice in organizations. It is seen that the results of the low level of justice in schools are examined by researchers in two variables: Organizational justice and job satisfaction (Altınkurt and Yllmaz, 2014; ClayWarner vd., 2005), organizational justice and exit (Örücü and Özafşarlıoğlu, 2013), organizational justice and loyalty (Fischer, 2004; Tulunay Ateş and Önder, 2017), and organizational justice and neglect (Withey and Cooper, 1989). It was also found out that all these studies examined the perceptions of teachers regarding organizational justice and their relations with some variables by using quantitative techniques. In Turkish literature, studies using qualitative techniques on how teachers experience and interpret inschool practices related to organizational justice have not been encountered. Similarly, it has not been questioned in a qualitative approach what kind of reactions teachers whose perceptions of organizational justice decreasing show. It is expected that the discovery of how teachers interpret their experience of organizational justice and what kind of behaviors they display in schools based on this interpretation will contribute to the related literature. The results obtained in this study are expected to contribute to the improvement of organizational justice practices on a school basis. In this regard, the answers to the following questions were sought in this research;

1. What are unfair practices in schools?

2. What are the emotional reactions of teachers to unfair practices?

3. What are the behaviors of teachers against unfair practices?

\section{Kaynakça / References}

Altınkurt, Y., ve Yılmaz, K. (2010). Değerlere göre yönetim ve örgütsel adalet ilişkisinin ortaöğretim okulu öğretmenlerinin algılarına göre incelenmesi. Kuram ve Uygulamada Eğitim Yönetimi, 16(4), 463-484. 
Altınkurt, Y., ve Yılmaz, K. (2014). Öğretmenlerin mesleki profesyonelliği ile iş doyumları arasındaki ilişki. Sakarya University Journal of Education, 4(2), 5771.

Şimşek, M. Ş., ve Aslan, Ş. (2012). Mesleki ve örgütsel bağlılığın örgütsel davranışa ilişkin sonuçlarla ilişkileri. Selçuk Üniversitesi İktisadi ve İdari Bilimler Fakültesi Sosyal ve Ekonomik Araştırmalar Dergisi, 12(23), 414- 454.

Budak, G., ve Sürgevil, O. (2005). Tükenmişlik ve tükenmişliği etkileyen örgütsel faktörlerin analizine ilişkin akademik personel üzerinde bir uygulama. Dokuz Eylül Üniversitesi İktisadi ve İdari Bilimler Fakültesi Dergisi, 20(2), 95-108.

Clay-Warner, J., Reynolds, J., ve Roman, P. (2005). Organizational justice and job satisfaction: A test of three competing models. Social Justice Research, 18(4), 391-409.

Colquitt, J. A., Greenberg, J., ve Zapata- Phelon, C. P. (2005). Hanbook of organizational justice. United States of America: Lawrence Erlbaum Associates.

Çelik, V. (1987). Teknik öğretmenlerin iş doyumsuzluğu ve öğretmenlikten ayrlmalarma etkisi. Yayımlanmamış yüksek lisans tezi. Ankara Üniversitesi Sosyal Bilimler Enstitüsü, Ankara.

Çıvgın, A. G. (2018). Platon'un adalet ve filozof kral anlayışı. Insan ve Toplum Bilimleri Araştırmalan Dergisi, 7(1), 221-229.

Çokluk, O., Oğuz, E., ve Y1lmaz, K. (2011). Nitel bir görüşme yöntemi: Odak grup görüşmesi. Kuramsal Eğitimbilim, 4(1), 95-107.

Dağlı, A., ve Ağalday, B. (2014). Öğretmenlerin örgütsel muhalefetin sonuçlarına ilişkin görüşleri. Akademik Sosyal Araştırmalar Dergisi, 2(1), 170-182.

Demir, C., ve Öztürk, U. C. (2011). Örgüt kültürünün örgütsel bağlllık üzerine etkisi ve bir uygulama. Dokuz Eylül Üniversitesi İktisadi ve İdari Bilimler Fakültesi Dergisi, 26(1), 17-41.

Doğan, H. (2002). İşgörenlerin adalet algılamalarında örgüt içi iletişim ve prosedürel bilgilendirmenin rolü. Akademik Bakış Dergisi, 2(2), 71-78.

Eklund, N. (2009). How was your day at school? Improving dialogue about teacher job satisfaction. Minnesote: Search Institute.

Eren, E. (2011). Yönetim ve organizasyon: Çă̆daş ve küresel yaklaşımlar. İstanbul: Beta.

Ertürk, A. (2003). Örgütsel iletişim ve adalet algilarının örgütsel kimlik algısı üzerindeki etkileri. Yönetim Araştırmalan Dergisi, 3(2), 147-170.

Farrell, D. (1983). Exit, voice, loyalty, and neglect as responses to job dissatisfaction: A multidimensional scaling study. Academy of Management Journal, 26(4), 596-607. 
Fischer, R. (2004). Rewarding employee loyalty: An organizational justice approach. International Journal of Organizational Behavior, 8(3), 486-503.

Folger, R., ve Konovsky, M. A. (1989). Effects of procedural and distributive justice on reactions to pay raise decisions. Academy of Management Journal, 32(1), 115-130.

Graham, J. W. (1991). An essay on organizational citizenship behavior. Employee Responsibilities and Rights Journal, 4(4), 249-270.

Grima, F., ve Glaymann, D. (2012). A revisited analysis of the exit-voice-loyaltyneglect model: Contributions of a longitudinal and conceptually extended approach. M@n@gement, 1(15), 1-41.

Greenberg, J. (1987). A taxonomy of organizational justice theories. Academy of Management Review, 12(1), 9-22.

Gürpınar, G. (2006). An empirical study of relationships among organizational justice, organizational commitment, leader-member exchange, and turnover intention Yayımlanmamış yüksek lisans tezi, Yeditepe Üniversitesi Sosyal Bilimler Enstitüsü, İstanbul.

Hirschman, A. O. (1970). Exit, voice, and loyalty. Responses to decline in firms, organizations, and states. England: Harvard University.

Hirschman, A. O. (1994). Except from chapter eight exit, voice, and loyalty: Responses to decline infirm, organizations and states. The Social Contract, 272275.

Hoy, W.K., ve Tarter, C. J. (2004). Organizational justice in schools: No justice without trust. International Journal of Educational Management, 18(4), 250-259.

İçerli, L. (2010). Örgütsel adalet: Kuramsal bir yaklaşım. Girişimcilik ve Kalkınma Dergisi, 5(1), 67-92.

İşcan, Ö. F., ve Sevimli, F. (2005). Bireysel ve iş ortamına ait değişkenler açısından iş doyumu. Ege Akademik Bakış Dergisi, 5(1), 55-64.

İşcan, Ö. F., ve Sayın, U. (2010). Örgütsel adalet, iş tatmini ve örgütsel güven arasındaki ilişki. Atatürk Üniversitesi İktisadi ve İdari Bilimler Dergisi, 24(4), 195216.

Kassing, J. W., ve Armstrong, T. A. (2002). Someone's going to hear about this: Examining the association between dissent- triggering events and employees' dissent expression. Management Communication Quarterly, 16(1), 39-65.

Kavak, O., ve Kaygın, E. (2018). Örgütsel adalet algısının örgütsel muhalefet davranışı üzerindeki etkisi. Balkan ve Yakın Doğu Sosyal Bilimler Dergisi, 4(1), 3351.

Koç, E. (2002). İnsan ve sadakat. Felsefe Dünyası Dergisi, 1(35),49- 57. 
Koç, H. (2009). Örgütsel bağlllık ve sadakat ilişkisi. Elektronik Sosyal Bilimler Dergisi, 8(28), 200-211.

Leck, J. D., ve Saunders, D. M. (1992). Hirschmans' loyalty: Attitude or behavior? Employee Responsibilities and Rights Journal, 5, 219-230.

Leventhal, G. S. (1980). What should be done with equity theory? Social exchange: Advances in theory and research. K. J. Gergen, M. S. Greenberg, \& R. H. Willis (Ed.). USA: Plenum.

Luthans, F. (2011). Organizational behavior: An evidence-based approach (12. bs.). USA: McGraw-Hill/Irwin.

Meyer, J. P., ve Allen, N.J. (1991). A three-component conceptualization of organizational commitment. Human Resource Management Review, 1(1), 61-89.

Mikula, G., Petri, B., ve Tanzer, N. (1990). What people regard as unjust: Types and structures of everyday experiences of injustice. European Journal of Social Psychology, 20, 133-149.

Miles, M. B., ve Huberman, A. M. (1994). Qualitative Data Analysis: An Expanded Sourcebook (2. bs.). Thousand Oaks, CA: Sage.

Nart, S., ve Yürür, S. (2016). Örgütsel adalet algısı kamu çalışanlarının ihbar etme niyetinin belirleyicisi midir? Amme İdaresi Dergisi, 49(3), 117-148.

Örücü, E., ve Özafşarlıŏlu, S. (2013). Örgütsel adaletin çalışanların işten ayrılma niyetine etkisi: Güney Afrika Cumhuriyetinde bir uygulama. Mustafa Kemal Üniversitesi Sosyal Bilimler Enstitüsü Dergisi, 10(23), 335-358.

Özer, P. S., ve Urtekin, G. E. (2007). Örgütsel adalet algisı boyutları ve iş doyumu ilişkisi üzerine bir araştırma. Erciyes Üniversitesi İktisadi ve İdari Bilimler Fakültesi Dergisi, 28, 107-125.

Özsoy Özmen, A. (2017). Kamuda güvencesizlik. İstanbul: Nota Bene.

Poyraz, K., Kara, H., ve Çetin, S. A. (2009). Örgütsel adalet algılamalarının örgütsel vatandaşlık davranışlarına etkisine yönelik bir araştırma. Süleyman Demirel Üniversitesi Sosyal Bilimler Enstitüsü Dergisi, 9, 71-91.

Rusbult, C. E., Zembrodt, I. M., ve Gunn, L. K. (1982). Exit, voice, loyalty and neglect: Responses to dissatisfaction in romantic involvements. Journal of Personality and Social Psychology, 43(6), 1230-1242.

Rusbult, C. E., Farrell, D., Rogers, G., ve Mainous, A. G. (1988). Impact of exchange variables on exit, voice, loyalty, and neglect. Integrative model of responses to declining job satistaction. Academy of Management Journal, 31(3), 599-627.

Skarlicki, D. P., ve Folger, R. (1997). Retaliation in the workplace: The roles of disrtibutive, procedural and interactional justice. Journal of Applied Psychology, 82(3), 434-443. 
Şahin, R., ve Kavas, E. (2016). Örgütsel adalet ile örgütsel bağlllık arasındaki ilişkinin belirlenmesinde öğretmenlere yönelik bir araştırma. Süleyman Demirel Üniversitesi Vizyoner Dergisi, 7(14), 119-140.

Yıldırım, A., ve Şahin H. (2016). Sosyal bilimlerde nitel araştirma yöntemleri. Ankara: Seçkin.

Topakkaya, A. (2009). Aristoles'te adalet kavramı. Uluslararası Sosyal Araştırmalar Dergisi, 2(6), 628-633.

Tulunay Ateş, Ö., ve Önder, E. (2017). Öğretmenlerin örgütsel adalet algısı ve örgütsel bağılıkları arasındaki ilişkiler: Türkiye'de yapılmış çalışmaların meta analizi. Turkish Studies: International Periodical for the Languages, Literature and History of Turkish or Turkic, 12(25), 589-608.

Türnüklü, A. (2000). Eğitimbilim araştırmalarında etkin olarak kullanılabilecek nitel bir araştırma tekniği: Görüssme. Kuram ve Uygulamada Eğitim Yönetimi, 24, 543-559.

Uysal, M. (2014). Genel liselerde görev yapan öğretmenlerin örgütsel adalet konusundaki algıları. Yayımlanmamış yüksek lisans tezi. Hacettepe Üniversitesi Eğitim Bilimleri Enstitüsü, Ankara.

Withey, M. J., ve Cooper, W. H. (1989). Predicting exit, voice, loyalty, and neglect. Administrative Science Quarterly, 34(4), 521-539.

Zhang, Y.J. (2016). A review of employee turnover influence factor and countermeasure. Journal of Human Resource and Sustainability Studies, 4, 85-91.

\section{Kaynakça Bilgisi / Citation Information}

Sağbaş, N. Ö. ve Özdemir, M. (2020). Okullarda örgütsel adalete ilişkin öğretmen deneyimlerinin incelenmesi. OPUS-Uluslararası Toplum Araştırmaları Dergisi, 16(Eğitim ve Toplum Özel Sayısı), 59115940. DOI: 10.26466/opus.711001 